PRZEGLĄD RUSYCYSTYCZNY 2020, nr 1(169)

DOI $10.31261 /$ pr. $\underset{\text { SA }}{\text { (i) (2) }}$

ZOJA NOWOŻENOWA

Uniwersytet Gdański

(DD ORCID https://orcid.org/oooo-00o3-3266-8251

\title{
МИСТИКО-ЭЗОТЕРИЧЕСКИЕ ЦЕННОСТИ VS. ЦЕННОСТИ МАССКУЛЬТУРЫ В КОММУНИКАТИВНО-РЕЧЕВЫХ ПРАКТИКАХ РОССИЯН: КОНФЛИКТ ИНТЕРЕСОВ
}

Легализация дискурсов с иррациональным модусом заметно изменила картину коммуникативно-речевых практик российского общества: сформировала в ней определенные дискурсивные формации, новые жанрово-речевые формы, корпус лексических инноваций, определенные словосочетательные синтаксические закономерности, необходимые для обслуживания социокультурных и ментальных проявлений носителей русского языка.

На специфику данных дискурсов и их коммуникативно-речевые (и, в конечном итоге, их языковые) особенности самым непосредственным образом повлияли определенные социально-культурные процессы, а также интеллектуально-ментальные настроения и состояния, отмеченные как в России, так и во всем мире.

Итак, культурно-социальные перемены в России привели к разрушению базовых идеологем коммунистического мировоззрения. В поведенческой и мировоззренческой составляющей жизни россиян усилились индивидуалистические и иррационалистические тенденции, трансформировались ценностно-смысловые составляющие жизни россиян, возросла ценность индивидуального существования, осознание нового измерения человеческого бытия. Государственный репрессивный аппарат 
перестал оказывать давление на религию, что привело к возрастанию демонстрации веры. Деидеологизация общественной жизни, крах коммунистической идеологии вызвали образование своеобразного духовного вакуума, который должен был заполниться. Именно эта брешь в общественном сознании начала заполняться конгломератом не всегда осознанных религиозных, философских, эзотерических и разного типа мистических представлений.

Можно сказать, что разные слои российского общества в силу своего образования, интеллектуального и духовного состояния, подготовленности и возможности принять новые ценности, обратились к новым для них духовным сферам. Поэтому в российском обществе наблюдается своеобразный ренессанс церковной духовности, возврат и укрепление на общественной сцене традиционных религий: христианства, прежде всего православия, католицизма, а также мусульманства, буддизма. В то же время формирование религиозного запроса привело к появлению «новых религий» ${ }^{1}$, активизации эзотерических и теософских течений, обращению к различного рода магическим, колдовским, парафилософским, парарелигиозным и паранаучным практикам. «В глазах скептического человека XX века престиж традиционной религии поколеблен; она теряет роль руководства в жизни »². Показательны данные, приводимые в российской прессе: от 11 до 13 процентов населения России настолько верят в колдовство и магию, что готовы обращаться за помощью к оккультистам. Почти $2 / 3$ россиян в принципе готовы обратиться за помощью к колдунам «в случае тяжелых жизненных обстоятельств». По данным опроса за 2012 г. «Левада-центра», к «эзотерикам когда-либо обращались $20 \%$ россиян, в то время как к профессиональным психологам - лишь 10\%. А 80\% опрошенных признались, что верят в различные астрологические и уфологические мифологемы» ${ }^{3}$.

Одной из причин усиления иррационалистической составляющей жизни россиян также является то, что в России об-

1 П.С. Гуревич, Культурология. Учебник для вузов, Gardariki, Москва 2003, c. 256.

2 Н.С. Юлина, Джордж Сантаяна: Воображение, живая вера и «царства бытия». Философская мысль в США ХХ в, «Kanon+» ROOI «Reabilitatsiya», Москва 2010, с. 149.

3 «Огонек» 2012, № 7 (20 февраля), https://www.kommersant.ru/ogoniok/67830 (15.10.2019). 
наруживаются типичные черты общества эпохи перемен, что особенно ярко проявилось в 90-е годы XX столетия. Основные черты кризисного состояния общества выявил Йохан Хейзинга, исследовавший ситуацию переходного периода в Европе конца 30-х гг. XX в. Они проявляются в шаткости общественной жизни, упадке культуры, нарушении равновесия материальных и духовных ценностей, доминации иррационального над рациональным, в отказе от идеалов познания, распространении суеверий, т.е. в иррационализации общественной жизни ${ }^{4}$ К Кроме того, этот внутренний российский процесс поддерживается тем, что современное культурное сознание в целом «отмечено ослаблением традиционных рационалистических структур мышления и усилением иррационалистических мотивов и настроений» 5 .

Факт усиления роли эзотерики в современном научном познании вызван также кризисом рационалистической философии: «Познание перестает отождествляется только с научным познанием, а сама наука оказывается один на один с огромной областью пограничных исследований (аномальных явлений, астрологии, парапсихологии), то есть с рядом нетрадиционных подходов и познавательных ориентаций» 6 . Под натиском иррациональных настроений доказательные знания теряют свои позиции. Ученые констатируют, что «действительно наука и культура в последние десятилетия испытывают все более усиливающееся давление со стороны иррациональных религиозно-мистических и эзотерико-магических концептов и представлений» ${ }^{7}$. Отмечается, что

на рубеже 60-70-х годов прошлого столетия обозначились первые признаки «магического Ренессанса», а в начале XXI века он уже превратился в одну из главных особенностей «нового культурного пространства»: не

4 Й. Хейзинга, Осень Средневековъя, перев. Д.В. Сильвестрова, «Наука». Москва 1988, с. 249.

5 К.З. Акопян (ред.), Массовая культура. Учебное пособие, Изд. Альфа-М, Москва 2004, с. 106.

6 Л.В. Щеглова, Ю.В. Борисова, Роль эзотерики в современном научном познании, «Вестник Волгоградского государственного университета. Серия 7. Философия. Социология и социальные технологии» 2015, №1, с. 23.

7 В.Ф. Чешко, Л.В. Иваницкая, В.И. Глазко, Постиндустриальная наука XXI века - рационализм versus иррационализм: эволюционно- билософский аспект, «Вестник российской академии естественных наук» 2011, №3, c. 69 . 
случайно постмодернизм все чаще характеризуется как «пространство неоархаики» ${ }^{8}$.

К поискам ответов на главные вопросы человеческого бытия, сформулированные Иммануилом Кантом - «что я должен знать? что я должен делать? на что я должен надеяться?» - которые Кант адресовал прежде всего философии, все более смело допускается эзотерика.

Эзотерика, эзотеризм трактуется как философское мировоззрение субъективного познания природы, доступное лишь ограниченному кругу лиц. Энциклопедия социологии определяет этот термин следующим образом:

Эзотеризм (от греч. esoterikos - внутренний) - англ. esoterism; нем. Esoterik. Тайное, скрытое от посторонних глаз, учение, знание, предназначенное исключительно для посвященных (оккультизм, мистика, теософия и т.д.) ${ }^{9}$.

Эзотеризм противопоставляется научному познанию, он исходит из сакральных знаний язычества и культивируется во многих культурах как некое тайное знание на уровне теософии и философии древних и современных культур. В сферу эзотеризма (эзотерики) включаются также оккультизм, магия, астрология, парапсихология, теософия и антропософия. Важно отметить, что эзотерика трактуется современной наукой как вненаучное знание, не представляющее собой одну традицию или единую систему знаний. Термин эзотерический понимается и определяется как 'тайный, скрытый, предназначенный для посвященных'. Именно такое понимание предлагает Философский энциклопедический словарь: эзотерический «(греч. - направленный внутрь) предназначенный только для избранных, для специалистов и понятный только им» ${ }^{10}$. Необходимо также отметить, что в России эзотерика все активнее становится объектом научного анализа и подвергается научной рефлексии ${ }^{11}$.

8 А.А. Пелипенко, В.М. Хачатурян, Когнитивные истоки «магического Ренессанса», «Человек» 2009, №3, с. 35.

9 А.А. Грицанов, В.Л. Абушенко, Г.М. Евелькин, Г.Н. Соколова, О.В. Терещенко (ред.), Социология: Энциклопедия, Knizhnyy dom, Минск 2003, c. 1229.

10 Л.Ф. Ильичев, П.Н. Федосеев, С. М. Ковалев, В. Г. Панов (ред.), Философский энциклопедический словарь, Республика, Москва 2010, с. 833.

${ }^{11}$ С. В. Пахомов, Специфика эзотерического знания в теории и практике. Мистико-эзотерические движения в теории и практике // С.В. Пахомов 
Источником формирования эзотерического дискурса, распространения эзотерических знаний, идей, ценностей в России является обширная литература, касающаяся проблем эзотерики (эзотерическая литература и литература об эзотерике), специальная пресса (газеты, журналы), а также сонники, словари имен собственных, содержащие мистико-эзотерическую (колдовскую) информацию, интернет-издания, с соответствующей тематикой.

К классическим эзотерическим текстам в узком понимании (метаисторическим текстам-первоисточникам) ${ }^{12}$ относят, например, такие древнейшие тексты, как тантры, мантры, Упанишады, средневековую еврейскую Каббалу и др. В русском эзотерическом дискурсе они присутствуют, как правило, в переводном варианте.

Кроме того, в дискурсе об эзотеризме, мистике, оккультизме эзотерическими также считаются тексты, выражающие принципы эзотерической философии, эзотерического мировоззрения, передающие эзотерическую информацию, эзотерические знания $^{13}$. Эзотерический текст может также описывать эзотерические техники, методы и практики духовного преображения человека. В отличие от текстов первоисточников данные тексты можно назвать интерпретирующими. Светлана Кузьминская, например, понимает под эзотерическим текстом произведения, которые традиционно связываются с восточной философской школой Махатм ${ }^{14}$. Такие тексты, как правило, отражают

(ред.), Проблемы интерпретации эзотеризма и мистицизма: Сб. материалов Третьей международной научной конференции, RHGA, СанктПетербург 2010; В.М. Розин, Эзотерический мир. Семантика сакрального текста, Москва 2002; В.А. Вовченко, Мистицизм, эзотеризм и оккультизм в духовной эволюции человечества // С. В. Пахомов (ред.), Мистико-эзотерические движения в теории и практике. Проблемы интерпретации эзотеризма и мистицизма, Санкт-Петербург 2010.

${ }_{12}$ См. В.Н. Назаров, Введение в эзотерику, Гардарики, Москва 2008, С. И. Кузьминская, Особенности функционирования метафоры в современном эзотерическом тексте // Доклад на международной научной конференции «Живая Этика и Культура. Идеи наследия семьи Рерихов в нашей жизни». Санкт-Петербургский Государственный Университет культуры и искусств, 10-11 февраля 2012, http://www.facets.ru/articles12/5028.htm (10.07.2019).

${ }^{13}$ См. об этом.: С.Р. Аблеев, Универсум сознания. Философские проблемы сознания в евразийском антропокосмизме, Амрита Москва 2010.

${ }_{14}$ С.И. Кузьминская, Особенности функционирования метафоры в современном эзотерическом тексте // Доклад на международной научной 
этическую, философскую, метафизическую, психологическую проблематику, содержат описание духовных практик, направленных на преображение внутренней сущности человека, и допускают как рациональный, так и иррациональный способы проникновения в суть излагаемых идей. Эзотерический текст, как правило, обладает некоторыми формальными признаками: он написан «эзотерическим языком», содержит эзотерические символы и знаки. Необходимо также отметить, что в литературоведении к эзотерическим текстам относят также тексты, в которых художник в своем идейно-художественном замысле воплощает эзотерические идеи и обращается к эзотерическим символам и смыслам ${ }^{15}$.

Начиная с XIX и на протяжении XX и XXI веков в России значительно расширился состав эзотерических текстов. В этот период получают распространение тексты Елены Блаватской, Генри Олкотта, Анни Безант, Кришнамурти, Ауробиндо Гхоша, Петра Успенского, Рудольфа Штейнера, Елены Рерих, Карлоса Кастанеды, Даниила Андреева, Дайсэцу Судзуки, Алана Уотса и др. Считается, что тексты Писем Махатм, Тайная Доктрина, Учение Храма, Живая Этика, Грани Агни Йоги наиболее полно отражают идеи Сокровенной Мудрости ${ }^{16}$. Исследователи также отмечают высокую степень присутствия в русском эзотерическом дискурсе переводной литературы ${ }^{17}$, которая особенно усилилась в 90-е гг. XX в. (например, Эстер и Джон Хиксы Учения Абрахама, серия книг Сан Лайта, Роберта Стоуна, Джо

конференции «Живая Этика и Культура. Идеи наследия семьи Рерихов в нашей жизни». Санкт-Петербургский Государственный Университет культуры и искусств, 10-11 февраля 2012: http://www.facets.ru/articles12/5028.htm (10.07.2019).

${ }_{15}$ См., например: M. Rzeczycka, Wtajemniczenie. Ezoteryczna proza rosyjska końca XIX - początku XX wieku, Uniwersytet Gdański, Gdańsk 2010; H. B. Петрунина, Эзотерический элемент какязыковой знак. (Наматериалелирики У.Б. Йейтса), «Вестник Томского государственного университета» 2011, №8.

${ }^{16}$ См. С. Р. Аблеев, Махатмы и этический гнозис: Формирование идейно $ф и-$ лософской традиции антропокосмизма, Проект ММ, Тула 2006; С. И. Кузьминская, екоторые характеристики эзотерического дискурса // «Universum: Филология и искусствоведение: электрон. научн. журн» 2014, №7, http://7universum.com/ru/philology/archive/item/1455 (2014.12.22).

17 А.А. Ворожбитова, Л.Л. Романенко, Эзотерический дискурс-ансамбль в системе дискурсивных процессов гносеологически ориентированной коммуникации российского социокультурно-образовательного пространства. Лингвориторический аспект, «Известия Сочинского государственного университета» 2013, №3. 
Витале Жизнь без ограничений, произведения Франка Кинслоу, Ога Мандино и др.).

Эзотерический дискурс закрепился и на российском телевидении (эзотерические программы и каналы такие, например, как «Душа ТВ», «Грани Бытия», «Эзо-TV» и др).

Значительно расширяется эзотерический дискурс в интернет-пространстве. Мы насчитали около 130 эзотерических сайтов (см., например, такие порталы, как эзотерический форум «Живое знание», «Медитурия - путешествия в медитации», «Математика Вселенной», сайты «Таролог», «Методики очистки эволюционного пути», «Магическое созвездие», «Техника Свободы», «Создай себя», «Астро-Оазис»; блоги «UFO/Инопланетяне», «Семинары/Мастер-классы», «Мистификации», «Мифические существа», «Наука и эзотерика», «Оккультизм», «Параллельные цивилизации» и др.).

В то же время наблюдается своего рода сращение эзотерического дискурса с текстами массовой культуры и рекламы ${ }^{18}$. Тексты этого сегмента публичной коммуникации некоторые исследователи называют псевдоэзотерическими ${ }^{19}$, так как в них не выражается, а эксплуатируется эзотерическая идея.

Таким образом, эзотерические и мистические идеи, смыслы, символы, ценности стали заметной составляющей интеллектуально-духовной жизни современного российского общества. Эзотерическое миропонимание обнаруживается в научном, философском, художественном, публицистическом, публичном, массмедийном пространстве. Проявляясь в различного рода текстовых и речевых произведениях (презентациях), в коммуникативно-речевых событиях, они обнаруживают определенные социально-речевые практики, формируют эзотерический дискурс и дискурс об эзотеризме.

Эзотерический дискурс можно определить как совокупность вербальных высказываний и невербальных продуктов, возникающих в связи с общественно-речевыми практиками в области эзотерики, а также практиками, допускающими полностью или частично знания и убеждения эзотерики, принимающими

${ }^{18}$ З.Л. Новоженова, Русский язык в новых дискурсивных пространствах: реклама... божественного // Мир русского слова и русское слово в мире, т. 3. Heron Press, Sofia 2007.

${ }^{19}$ Е.В. Зорина, Русская метафизика и эзотерическая традиция. XX век, Марийский государственный университет, Йошкар-Ола 2000. 
эзотерическое объяснение человека и мира. Основными функциями эзотерического дискурса является изложение содержания эзотерического мировоззрения, пропаганда эзотерических взглядов на мир, поиски адептов, обслуживание эзотерических практик, использование, эзотерики в целях манипуляции. Интерпретация мира в этом типе дискурса определяется эзотерической позицией субъектов дискурса, системой его ценностных эзотерических установок.

Эзотерический дискурс, кроме прочих конститутивных признаков когнитивного и прагматического характера (цели, стратегии, участники, жанры, хронотоп и др.), обладает также системой ценностей. Именно ценности, по мнению Нины Арутюновой, выполняют координирующую (между человеком и миром объектов), стимулирующую (направляющую деятельность), дидактическую и регулирующую (прескрептивную) функцию в механизмах жизни ${ }^{20}$.

Эзотерические ценности базируются на эзотерическом миропонимании и на эзотерическом знании. «Эзотерическое знание в отличие от научного не является рациональным. Оно носит иррациональный характер апеллирует к бессознательному, к воображению. Эзотерическое знание есть знание интуитивное» ${ }^{21}$. Эзотерические знания весьма обобщенно можно свести к следующим положениям: вера в существование иной, «подлинной», реальности, особое понимание и постулирование универсальности законов мироустройства, понимание времени как нелинейного, цикличного, повторяющегося; возможность автономности человеческого сознания, стремление к синтезу философского, религиозного и эзотерического опыта; поиски путей гармонизации психического состояния человека. «Среди основных идей, которые последовательно рассматриваются и утверждаются данной системой текстов, можно выделить следующие: сложность онтологической структуры мироздания, дальнейшая эволюция человека, многомерность человеческой природы, возможность инобытия человеческого сознания, синтез различных форм познания действительности и др.» ${ }^{22}$.

${ }^{20}$ Н.Д. Арутюнова, Язык и мир человека, Языки русской культуры, Москва 1999, c. 60.

${ }^{21}$ А.В. Панычик, Социально-философский анализ эзотеризма. Автореф. дис. на соиск. учен. степ. к. филос. н., Ростов-на-Дону 2002.

${ }^{22}$ С. Р. Аблеев, Универсум сознания...; В. Н. Назаров, Введение в эзотерику... 
Безусловно, эзотерической ценностью является признание того, что «все явления и действия реального мира обусловлены тонким миром и неподвластны нашему пониманию», а также холистический взгляд на мир, признающий глубинную взаимосвязанность всех вещей: «взгляд на мир как на единое целое, а не собрание разрозненных частей» ${ }^{23}$. Эзотерические ценности являются прерогативой адептов эзотеризма, но вместе с тем они в разной степени (в разном объеме, с разной степенью осознанности, с различными целями и разным критическим отношением к ним) осваиваются различными слоями российского общества, активно проникают в публичное пространство, а также подвергаются медиатизации (наряду с религией). Так, Стиг Хьярвирд приводит один из факторов, свидетельствующих о медиатизации религии и религиозных ценностей, ему вторит российский исследователь «[...] в процессе медиатизации СМИ становится главным субъектом, влияющим на формирование представления о религии и религиозных ценностях в публичной сфере» ${ }^{24}$. Подобному процессу медиатизации в полной мере подвергается и эзотерика.

Как указывалось выше, проникновение эзотерического знания и ценностей в публичное медийное пространство отражается в коммуникативно-речевых дискурсивных практиках россиян, в том числе и на уровне речевых средств и жанрово-текстовых образований. Данные коммуникативно-речевые процессы можно обнаружить и на лексическом уровне (в лексическом наполнении эзотерических текстов).

Эзотерическое знание, эзотерическая «идеология» определяют ономасиологические аспекты текстообразования: они создают «свое» эзотерическое текстовое пространство ${ }^{25}$. Эзотерический текст, как показал наш анализ, обнаруживает тематические цепочки номинативно-лексических средств (тезаурус дискурса/

${ }^{23}$ Ф. Капра, Паутина жизни. Новое научное понимание живых систем. Пер. с англ. под ред. В.Г. Трилиса, ИД «София», Москва 2003.

${ }^{24}$ В.М. Хруль, Медиатизация религиозных ценностей как фактор формирования культуры диалога в российской журналистике, «Вестн. Моск. УНта, Сер. 10, Журналистика» 2012, №1, с. 61.

${ }^{25}$ См. об этом 3. Новоженова, Коммуникативно-функциональные свойства новых русских эзотерических текстов // Русистика и современность. Старые вопросы, новые ответы. И. Любоха-Круглик, О. Малыса, Г. Вильк, А. Зых (ред.), Śląsk-Stowarzyszenie Inicjatyw Wydawniczych, Katowice 2017, c. $457-475$. 
текста), которые формируют специфическое семантико-смысловое пространство текста ${ }^{26}:$ материя, сознание, энергия, информация, слово, космическое всезнание, духовная эволюция, сверхлюди, сверхсущества, эфирные оболочки, любовь, красота, терпимость, жертва, Вселенная, помощь, опекунство, кураторство, мир, человечество, душа, сознание, судъба, посвящение, высший разум, манада, искра божъя и др. Эзотерическое знание способствует насыщению эзотерического текста специальной терминологией (медитация, нумерология, астрология, реинкарнация, магия, мистика, оккультизм, спиритуализм, каббала, теософия, антропософия, космоэнергетика, биоэнергетика и др.) и особыми иноязычными заимствованиями (телекинез, левитация, реинкарнация, ксеноглоссия и т. д.), а также текстовыми дискурсивными иноязычными вкраплениями: «Веды утверждают, что существует три вида страданий: адхьятмика, адхибхаутика и адхидайвика ${ }^{27}$.

В создании тезауруса эзотерического дискурса участвуют и устойчивые сочетания (клише, речевые штампы, фразеологизмы и под.). Активизация эзотерического дискурса способствует формированию в нем новых словосочетательных связей и возникновению внутритекстовых устойчивых словосочетаний, таких как, например, Живая Этика, тайная доктрина, расширенное сознание, чистое сознание, измененное (состояние) сознание, Тонкие Тела, эфирное тело, Божественный план, диагностика ауры, четвертый путь, сила мысли, Вознесенные Мастера, Учителя Человечества, высшее планетарное Братство, эфирная оболочка, астральный план, энергетический канал, энергоинформационные структуры и др.

Часто словосочетательные связи дают метафорический эффект и выражают символические смыслы: фокус энергии, непрерываемое сознание, просветленная память, высшая энергетическая связь, страшное время, эфирные оболочки, Вознесенные Владыки, Владыки мудрости, Священный Высший Разум, Сокровенная мудрость, Третий глаз, луч преданности и др.

Об увлеченности российского общества эзотерическими идеями и ценностями свидетельствует наш анализ эзотерической

${ }^{26}$ В данном случае текстами для анализа послужили в основном тексты эзотерических трактатов, эссе, наставлений.

${ }_{27}$ Р. Михайлов, Тройственные страдания, https://audioveda.ru/tags/69 (10.07.2019). 
фразеологии (ушел в астрал ${ }^{28}$, повторять как мантру ${ }^{29}$ ). Все чаще и в медиапространстве фиксируются различные жанровые разновидности эзотерического дискурса. В целом в соответствии с прагматическими целеустановками и интенциями говорящего субъекта жанровые разновидности эзотерических текстов можно разделить на три группы: 1) тексты, интерпретирующие и демонстрирующие эзотерическое знание и познание, тексты о мироздании (эссе, трактаты, послания, наставления и под.); 2) тексты суггестивные, описывающие практики самоусовершенствования и пропагандирующие возможности и пути духовного перерождения (наставления, послания и нек. др., инструкции по духовным практикам); 3) тексты, указывающие на эзотерические знаки и символы (сонники, астрологические прогнозы, гороскопы, словари имен собственных, профетические тексты). Жанровое разнообразие эзотерических текстов дополняют также мистические и оккультные тексты, прорицания, откровения, профетические тексты (провидения и предсказания), гримуары, которые представляют собой учебники магии, инструкции по изготовлению амулетов, талисманов, вызову духов, астрологические прогнозы, эзотерическая публицистика, беллетристика и нек. др.

Именно данные текстово-жанровые образования, как правило, являются трансляторами эзотерических ценностей в публичное медийное пространство.

Однако попадая в СМИ, эзотерические ценности испытывают мощное давление массовой культуры. Носитель массового сознания, поверхностно и неосознанно усвоив мистико-эзотерические ценности (холистическую идею, идею автономности сознания, ограниченно принимая принцип причинно-следственных отношений и проч.), вырабатывает поверхностно-схематированный вариант эзотерики и достаточно примитивный компендиум эзотерических знаний (астрал, мантра, йога, чакры, расширенное сознание и др.), и в конечном итоге остается во власти ценностей массовой культуры. А как известно, основной ценно-

${ }^{28}$ З.Л.Новоженова, «Ушел в астрал и не вернулся...» Эзотерические фразеологизмы. Замечания кнаблюдениям//A. Pstyga (red.), Stowo zperspektywy językoznawcy i ttumacza, Uniwersytet Gdański, Gdańsk 2018, c. 114-125.

29 З.Л. Новоженова, Новая русская фразеология: эзотерический вектор // В. Аврамова, А. Пенчева, Г. Гочев и др. (ред.), Русистика: вчера, сегодня, завтра, Общество русистов Болгарии, София 2018, с. 183-193. 
стью массового человека, его жизненной функцией становится принципиальное и радикальное потребительство. Таким образом, тиражирование идеи эзотерики, которая проходит под лозунгом «эзотерику - в массы!», безусловно, приводит к девальвации и банализации эзотерических ценностей, к обеднению их смыслов. Массовая культура, как известно, касаясь даже самых сложных проблем веры, интуиции, идеалов, бытия, сознания, Вселенной и др. всегда идет по пути упрощения. В ряду ценностей массовой культуры называются ${ }^{30}$ богатство, деньги, секс, культ грубой силы, слава, прагматизм, собственность, а также гедонистические ценности - удовольствие, комфорт, успех, благополучие, сила, здоровье и нект. др..$^{31}$

В сегменте медиапространства наблюдается своего рода взаимопроникновение эзотерических ценностей и ценностей массовой культуры, сращение эзотерического дискурса с текстами массовой культуры и рекламы.

Возможно, «главными» эзотерическими текстами, которые функционируют в массмедийном пространстве, являются гороскопы и эзотерическая реклама, так как именно они количественно преобладают и целенаправленно транслируют некоторые представления о действительности в массовое сознание социума. Обратимся сначала к самому, пожалуй, популярному из них - гороскопу.

В основе жанрово-текстовой организации классического гороскопа лежит многоуровневая астрологическая система ${ }^{32}$. Классический астрологический прогноз (гороскоп) имеет свой устоявшийся канон, который базируется на архаическом слое (архетипы и мифологемы), а также включает образный (метафоры и другие тропы), характеристический слой. Особый слой представлен практическими рекомендациями, что определенным образом отражается и на его трехчастной структуре: 1) описание карты неба и расположения планет, 2) интерпретация

${ }^{30}$ См. напр. А.А. Зиновьев, На пути к сверхобществу, ЗАО Изд-во Центрполиграф, Москва 2000, с. 371.

${ }^{31}$ См. С. С. Ильченко, Ценности «массовой культуры»: перспективы научного осмысления, «Вестник Санкт-Петербургского университета, Журналистика», сер. 9, 2008, №1.

$3^{2}$ Санкт-Петербургская астрологическая академия (СпбАА): http://www.astroacademy.spb.ru; Astrologo.ru, Профессиональные гороскопы: http://astrologo. ru/natal/; Vgoroskope - научная астрология и современные технологии: https://vgoroskope.ru (10.07.2019) 
влияния расположения планет на события, 3) рекомендации. Он написан специальным «эзотерическим» языком, отличается достаточно большим объемом и, как правило, содержит графическое изображение астрологической карты (натальной карты). Авторами классических астрологических прогнозов являются люди, считающие себя профессионалами (астрологами), обладающими специальными знаниями.

В то же время астрологический прогноз становится одним из популярнейших жанров массовой культуры. Однако в массмедийном пространстве жанр гороскопа переживает значительную трансформацию.

Гороскопы публикуются во многих российских современных газетах и журналах, прежде всего в журналах мод и женских журналах: «Elle», «Cosmopolitan», «Burda», «Крестьянка», «Лиза», «Комсомольская правда», «Московский комсомолец» и др. Они помещаются в интернет-порталах, существуют отдельные сайты, посвященные только эзотерическим прогнозам. Примерами гороскопов могут быть следующие тексты:

ВЕСЫ - Текущее положение звезд свойственно для начала эмоционального разнообразия. Именно это сейчас и происходит в Вашем астрологическом доме семьи, жилья и чувств. Что ж, не стоит и упоминать, как много всего происходит в Вашей жизни, даже если эти события не столь очевидны для сторонних наблюдателей. Однако окажите себе услугу. Возьмите быка за рога и сами сделайте первый шаг. Если сможете самостоятельно во всем разобраться, у Вас будет реальной повод для гордости ${ }^{33}$.

БЛИЗНЕЦЫ - В ваших чувствах царит спокойствие и гармония. Четверг и пятница прекрасны для встреч и свиданий. Если вы были в ссоре с любимым человеком, то обязательно помиритесь. А воскресенье - просто райский день: в ваших отношениях полное взаимопонимание и единодушие ${ }^{34}$.

БЛИЗНЕЦЫ - Если Близнецам выпадает шанс взяться за рискованное, но прибыльное предприятие, не нужно бояться - вы совсем справитесь блестяще.

РАК - Не стоит хвататься за новое, лучше с чувством и толком завершите начатые дела. Совесть будет спокойной, а кошелек толстым ${ }^{35}$.

ОВЕН - Готовьтесь к тому, чтобы взять командование в свои руки. Вы просто фонтанируете удачными идеями ${ }^{36}$.

КОЗЕРОГ - Постарайтесь сегодня провести немного времени на природе. Свежий воздух и природные красоты окажут на Вас расслабляющее

$33 \mathrm{http}: / /$ horo.ukr.net (10.07.2019)

${ }^{34}$ http://www.astromeridian.ru (10.07.2019)

35 «Караван историй», ноябрь 2018, №11.

${ }^{36}$ Там же. 
действие - но в то же время, это взбодрит Вас и даст несколько идей на счет того, чего Вы хотите от жизни. К тому же, занимаясь обычными житейскими проблемами, Вы сможете оставаться более приземленным и уравновешенным. Вы пытались найти какое-то решение, и после времени, проведенного на свежем воздухе, Ваш разум (а вместе с ним и выбор) станет яснее ${ }^{37}$.

Попадая в медийное пространство, гороскоп под действием требований и ценностей масскультуры теряет многие черты астрологического жанрового канона. Во-первых, такой гороскоп значительно сокращается в объеме, однако пытается сохранить трехчастное деление, и самое главное, смысловую и тематическую доминанту. На это обращают внимание исследователи: «эзотерический гороскоп, помещенный в медиапространстве, декларирует знания о влиянии небесных тел на судьбу человека и земные события, согласно которым их можно предсказать по взаимному расположению небесных тел» ${ }^{8}$.

Таким образом сохраняется главная эзотерическая цель гороскопа - сообщение о влиянии расположения звезд на каждый знак зодиака, т.е. на представителей того или иного знака, и, в связи с этим, даны рекомендации для их поведения в определенном отрезке времени.

Однако коммуникативная, прагматическая цель гороскопа в массмедийном пространстве иная - развлекательная, гедонистическая, «успокоительная». Массовая культура расставила иные акценты, изменила природу этого жанра. Многие исследователи относят астрологический прогноз к жанрам массовой литературы, рассчитанным на читателя-потребителя ${ }^{39}$. Автором его является литературный работник, журналист.

Для эзотерических и квазиэзотерических текстов, к которым необходимо отнести гороскопы, а также эзотерическую рекламу, о которой мы будем говорить ниже, характерными являются осо-

37 http://orakul.com (10.07.2019)

${ }^{8}$ Е. В. Бабаева, Лингвокультурологические характеристики русской и немецкой аксиологических картин мира, Автореф. дис. канд. филол. наук, Волгоград 2004.

${ }^{39}$ См. например: Е. В. Бабаева, Тексты гороскопов как отражение социальных ценностей и норм // Ю.А. Сорокина, М.Р. Желтухина (ред.), Массовая культура на рубеже $X X-X X I$ веков: человек и его дискурс, Азбуковник, Москва 2003; О.В. Карпова, Астрологический прогноз как жанр массовой литературы. Образ читателя-потребителя, «Филология в системе современного университетского образования» 2004, №7. 
бые стратегии называния, так как именно номинативные единицы позволяют построить другую, мистическую, эзотерическую реальность, о которой Ролан Барт пишет: «Эти тексты служат, чтобы заклинать реальность, именуя ее»40. Таким образом, первая характерная языковая черта гороскопов - это их лексическое наполнение: характер номинативных рядов в них определяется коммуникативно-прагматическими интенциями автора и тематической направленностью гороскопа (которую можно определить как предмет разговора, предмет коммуникации). Это, как правило, такие темы, как здоровье, карьера, новые знакомства, любовь, семейные отношения, финансы и под., - то есть все то, что лежит в сфере так называемых личных интересов человека. Можно встретиться с утверждением, что «астрологический прогноз как литература «мелкобуржуазного» мира в концентрированном виде представляет идеи массовой литературы» ${ }^{41}$. В целом это утверждение верно. И в этой связи хочется вспомнить расхожее мнение о том, что есть только три вещи, о которых следует писать: «любовь, смерть и деньги». Представляется, что массовая литература и культура отличаются от «настоящей» не столько характером проблем, сколько способом их постановки и разрешения.

Языковые особенности гороскопа, которые несут на себе «тяжесть» реализации прагматических и гедонистических ценностей, обнаруживаются в разноуровневом составе языковых средств (единиц). Так, в медийном гороскопе практически отсутствует мистическая тональность классического гороскопа: она подменяется шутливо-«приятельской» тональностью ${ }^{42}$. Эта стратегия конструирования текста требует использования разговорного стиля, наличия жаргонизмов и сниженнойлексики: (хвататься за новое, толстый кошелек, фонтанировать идеями, с чувствоми толком завершить дела), фразеологизмов (возъмите быка за рога, сделайте первый шаг, реальный повод, выпадает шанс, совесть будет спокойной, дарит спокойствие,

40 Р. Барт, Мифологии, пер. С. Зенкин, Изд. им. Сабашниковых, Москва 20оо, c. 209.

${ }^{41}$ О. В. Карпова, Астрологический прогноз как жанр массовой литературы. Образ читателя-потребителя, «Филология в системе современного университетского образования» 2004, №7, с. 25.

42 3. Л. Новоженова, Модальность и тональность в эзотерическом тексте // И.Ю. Кукса (ред.), Категория модальности в речевой коммуникации: сб. науч.тр., Изд. БФУ им. И. Канта, Калининград 2016, с. 179. 
райский денъ, природные красоты и др.). В медийном гороскопе может появляться и модное иноязычное заимствование из английского языка, американизмы, что совершенно не характерно для классического гороскопа. Вероятностный и необязательный характер медийного астрологического прогноза диктует и некоторые его грамматические особенности: для первой части прогнозов характерно будущее время (у вас в судъбе произойдут значительные изменения, вас ждет финансовых успех, наблюдается повышение умственных возможностей и т.д.) и особая модальность возможности, которая оформляется с помощью модальных глаголов может, можете и модальных слов возможно, может быть и под. (например, вы можете допустить неточности, вы можете отказаться от дополнительной работы, в вашей жизни может случиться что-то приятное, возможно вас посетит тещза).

Краткость изложения, ясность риторических приемов делает очевидным, доступным содержание гороскопа, не требующего от адресата интеллектуальных усилий: создается некоторый психологический комфорт, проистекающий из общей комплиментарности текста и направленности его содержания на личность читателя. В конечном итоге это способствует реализации в данном типе текстов развлекательной функции, гедонистических и прагматических идеалов общества потребления. Астрологический прогноз, реализуя фактор адресата, как правило, имеет возрастную, социальную или гендерную адресованность.

Другим жанром, активно функционирующим в медиапространстве, является эзотерическая реклама, обслуживающая колдовские иррациональные практики, деятельность магов, целителей, экстрасенсов и под. Реклама в качестве медийного жанра относится к жанрам массовой культуры. Однако эзотерическая реклама принимает на себя также функцию транслирования определенных эзотерических смыслов и ценностей. В результате реклама как жанрово-текстовое образование переживает определенную трансформацию:

(1) Международная Академия Инновационной Парапсихологии

Возможности человека безграничны, их просто необходимо разблокировать. Обучение магии у Михаила Карса позволит вам не только профессионально овладеть магическими техниками, но и научиться более глубоко проникать в суть выполняемых вами ритуалов. 
(2) Лаборатория практической магии

Организация объединяет лучших Алтайских магов и целителей, которые ведут консультативно-практическую деятельность в круглосуточном режиме.

Магическая династия. Тайные знания древних. Возможности современности.

Прямая диагностика по фото, очно, через средства виртуальной связи Интернет._Просмотр событийного ряда через карты. Прямое ясновидение. Вызов покойных. Медиум...

(3) Я Вам помогу! Снятие сглаза и порчи. Помощь в решении семейных и личных проблем. Диагностика кармы. Бизнес прогноз. Предпродажная подготовка эзотерическим практикам.

Магия, предсказание, гадание, снятие порчи.

Магия, Теософия, Карма, гипноз, гадания, также увидеть паранормальные силы, которые заложены в нас самих, это тоже видимое проявление Бога. Стань сильнее колдовства и негативного воздействия!

(4) Заочный тренинг - специализированный эзотерический курс Защиты от негативного целенаправленного и бытового воздействия, для приостановления текущего влияния...

(5) Дети до 10 лет консультируются за символическую плату; Внимание: в июне состоятся посвящения с 50\% скидкой в каналы: Св. Будда, Св. Моисей, Св. Мухаммед, Св. Иисус, Агни, Хум, Агни-Хум. Информация по телефону.

(6) Сеньорита Гиацинта: Предсказания и определение причин Ваших проблем на Таро, Рунах, с помощью авторских методик. Коррекция ситуации. Колдовство любое на заказ: любовная и денежная магия, открытие удачи, снятие негатива и постановка защиты, наказание врагов. Лечение бесплодия. Обо мне: http://www.magic-gallery.com Медицинские консультации (акушерство и педиатрия). Помогаю справиться с проблемными кожей и волосами и с лишним весом. Гостей не консультирую.

Специализация: Эзотерика (Гадания онлайн, Магия, Биоэнергетика, Парапсихология, Фэн-шуй, Хиромантия, Толкование сновидений, Таро, Руны, Целители, Мистика, Нумерология, Экстрасенсы, Обереги, талисманы); Медицина (Фармация, Гомеопатия, Педиатрия, Беременность и роды, Классическая медицина), Красота, Здоровье (Косметология, Нетрадиционная медицина, Здоровое питание, Спорт, Имидж и стиль, Восточная медицина, Рэйки, Аюрведа, Литотерапия, Ароматерапия $)^{43}$.

Как видно из приведенных текстов, дискурсивный код совмещает в них, с одной стороны, черты рекламных манипуляций, с другой, проявляет иррациональные ментальные установки. Эти тексты имеют некоторые формальные признаки рекламы: слоган, рекламный девиз, сведения об услугодателе, информация об услуге, реквизиты. Кроме того, в лексическом составе текстов реклам можно отметить единицы с определенной се-

43 https://www.liveexpert.ru/e/femme-chatte (12.03.2019) 
мантикой, вносящих в текст ощутимую долю здорового прагматизма, деловитости и коммерческих отношений весьма далеких от эзотерических ценностей: Международная Академия (1), Лаборатория (2), Организация (2), Интернет (2), бизнес-прогноз (2), консультационно-практическая деятельность (2), информация по телефону (5), авторские методики (6), специализация (7), имидж (7), предпродажная подготовка (3).

В свою очередь, иррациональный вектор отбирает для создания текста особые специфические языковые единицы. Так, в данных текстах отсутствует характерная для современной рекламы экспрессивная составляющая (экспрессивная лексика, языковая игра, фразеологизмы, жаргонизмы), а характер заимствований отличается от типичных для рекламы (как правило, в них отсутствуют англицизмы и американизмы).

Таким образом, смысловое пространство эзотерического рекламного текста формируется различными тематическими цепочками номинативно-лексических средств (тезаурс дискурса/ текста). Лексический состав текстов, как уже говорилось, с очевидностью проявляет их иррациональный модус, свидетельствующий о наличии эзотерических ценностей в смысловом пространстве текста: порча, сглаз, родовое проклятие, зеркальная защита, гадания, отворот, приворот, остуда, аура, чакра, талисман-оберег, духовная чистка, руны, предсказания, колдовство, гадания, карма, астрал, аюрведа и под. Эксплуатация эзотерического знания и эзотерических ценностей способствует насыщению эзотерической рекламы специальной терминологией: медитация, нумерология, астрология, реинкарнация, магия, мистика, оккультизм, спиритуализм, каббала, теософия, антропософия, космоэнергетика, биоэнергетика, руны, таро, экстрасенсы, медиум, чакры и др., что способствует созданию особой мистической тональности текстов ${ }^{44}$. Для данных текстов характерен особый концептуальный фон, фиксирующий «конфликт интересов», который выражается через такие концепты, как судъба, посвящение, любовъ, болезнь, с одной стороны, и бизнес, денъги - с другой стороны. Процессы семантической изотопии, возникающие в дискурсе, вызывают в данных текстах изменение семантики слов и концептуальных ценностных смыслов, выражаемых фундаментальными философскими и религиоз-

44 З. Л. Новоженова, Модальность и тональность в эзотерическом тексте..., c. 179. 
ными понятиями (например, Бог, вера, посвящение и под.). Как правило, этот процесс ведет в сторону их девальвации. Так, в достаточно малом текстовом пространстве прагматика ситуации объединяет трансцендентные и бытовые смыслы: Aлтайские маги и целители [...] ведут консультативно-практическую деятельность в круглосуточном режиме (2); [...] состоится посвящение с пятидесятипроцентной скидкой в каналы св. Будды, св. Моисея и св. Иисуса... (5); Диагностика кармы и бизнес-прогноз (3); Любовная, денежная магия, колдовство на заказ (6) и под.

Целенаправленный отбор номинативных средств является наиболее естественным языковым инструментом речевого воздействия в дискурсе. Павел Паршин замечает, что «в силу разнообразия лексической семантики выбор слов оказывается универсальным инструментом, с помощью которого осуществляются самые разные виды воздействия» 45 .

«Называть социальные явления - значит вызывать их к жизни» ${ }^{46},-$ писал в свое время известный социолог Пьер Бурдье. Именно через номинацию явлений в тексте современные маги, целители, колдуны показывают свою власть над действительностью. Следуя мистической и эзотерической логике, события реальной жизни, фиксируемые эзотерической рекламой, определены «нерациональными» обстоятельствами: сглазом, психоэнергетикой, негативным воздействием, родовым проклятием и под. Убеждающая манипуляция проявляется также в создании коммуникативных типажей, масок. Этой цели служат имена собственные (Габриэла, Гиацинта, Жермена и под.), использование статусных титулов и званий (академик ясновидения и иелительства, Магистр Высшей Магии Международного класса, потомственная колдунъя, Сеньорита Гиациинта и под.).

Генеральной когнитивной стратегией, которая осуществляется в подобного типа текстах, является стратегия онтологизации знаний, т.е. интеграция знаний и ценностей адресанта в модель мира адресата. Она происходит при помощи вариативной интер-

45 П.Б. Паршин, Природа речевого воздействия: http://files.school-collection. edu.ru/dlrstore/4be4c29o-3db5-c4ef-05a5-6aac5078c5b3/1009689A.htm (10.07.2019)

${ }^{46}$ П. Бурдье, Социология политики, Socio-Logos, Москва 1993. 
претации действительности ${ }^{47}$ и тактики навязывания пресуппозиции. В конечном результате это может привести к формированию новой картины мира у адресата, или, в случае неприятия предлагаемой интерпретации действительности, создает у него когнитивный и познавательный диссонанс, то есть может выработать позитивное или негативное отношение у адресата к предмету сообщения.

Тексты проанализированных двух жанров - гороскопа и эзотерической рекламы - свидетельствуют о формировании в массмедийном пространстве дискурсивных формаций, проявляющих социальные практики, ментальные установки, систему ценностей и коммуникативные потребности современного российского общества. Эзотерическая реклама и гороскоп являются специфическими жанрами, создаваемыми на основе особой коммуникативно-когнитивной программы, включающей иррациональные ментальные установки и ценности, а также ценности и прагматику массовой культуры. Эта программа обусловливает целенаправленный отбор речевых и языковых средств, направленный, в конечном итоге, на изменения как индивидуального, так и общественного сознания, или, в терминах когнитивной лингвистики, картины мира адресата.

Современное медиапространство в жанрах гороскопа и эзотерической рекламы демонстрирует конкуренцию эзотерических ценностей и ценностей масскультуры. Эзотерический дискурс массмедиа использует достижения современной информационный индустрии, эксплуатирует положения и понятия религии и философско-интеллектуальных течений, а также использует приемы, методы и «идеалы» массовой культуры, демонстрируя речевую системность в отборе и качестве языковых средств для создания порядка дискурса.

\section{БИБЛИОГРАФИЯ}

Ableyev, Sergey. Makhatmy i eticheskiy gnozis: Formirovaniye ideyno-filosofskoy traditsii antropokosmizma, Tula: Proyekt MM, 2006 [Аблеев Сергей, Махатмы и этический гнозис: Формирование идейно-философской традиции антропокосмизма, Тула: Проект ММ, 2006].

47 А.Н. Баранов, П.Б. Паршин, Языковые механизмы вариативной интерпретации действительности как средство воздействия на сознание // Роль языка в средствах массовой коммуникации, ИНИОН, Москва 1986. 
Ableyev, Sergey. Universum soznaniya. Filosofskiye problemy soznaniya $v$ yevraziyskom antropokosmizme. Moskva: Amrita, 2010 [Аблеев C.P., Универсум сознания. Философские проблемы сознания в евразийском антропокосмизме. Москва: Амрита, 2010].

Akopyan, Karen (Ed.). Massovaya kul'tura. Uchebnoye posobiye, Moskva: Izd. Al'fa-M, 2004 [Акопян, Карен (Ред.). Массовая культура. Учебное пособие. Москва: Изд. Альфа-М. 2004].

Arutyunova, Nina. Yazyk i mir cheloveka. Moskva: Yazyki russkoy kul'tury, 1999 [Арутюнова, Нина. Язык и мир человека. Москва: Языки русской культуры, 1999].

Babayeva, Yelena. "Teksty goroskopov kak otrazheniye sotsial'nykh tsennostey i norm.” Sorokina Yulia, Zheltukhina Marina (Ред.). Massovaya kul'tura na rubezhe XX-XXI vekov: chelovek $i$ yego diskurs. Moskva: 2003 [Бабаева, Елена. “Тексты гороскопов как отражение социальных ценностей и норм." Сорокина, Юлиа. Желтухина, Марина (Ред.). Массовая культура на рубеже XX-XXI веков: человек и его дискурс. Москва: Азбуковник, 2003].

Babayeva, Yelena. Lingvokul'turologicheskiye kharakteristiki russkoy $i$ nemetskoy aksiologicheskikh kartin mira. Avtoref. dis. kand. filol. nauk, Volgograd: 2004 [Бабаева, Елена. Лингвокультурологические характеристики русской и немецкой аксиологических картин мира. Автореф. дис. канд. филол. наук. Волгоград: 2004].

Baranov, Anatoliy, Parshin, Pavel. "Yazykovyye mekhanizmy variativnoy interpretatsii deystvitel'nosti kak sredstvo vozdeystviya na soznaniye.” Bezmenova Natal'ya, Luzina Lyudmila (Ред.). Rol' yazyka v sredstvakh massovoy kommunikatsii. Moskva: INION, 1986 [Баранов, Анатолий, Паршин, Павел. “Языковые механизмы вариативной интерпретации действительности как средство воздействия на сознание.” Безменова Наталья, Лузина Людмила (Ред.). Роль языка в средствах массовой коммуникации. Москва: ИНИОН, 1986].

Barthes, Roland. Mifologii. Transl. Zenkin, Sergei. Moskva: Izd-vo im. Sabashnikovykh, 2000 [Барт Ролан. Мифологии. Пер. Зенкин, Sergei. Москва: Изд-во им. Сабашниковых, 2000].

Bourdieu, Pierre, Sotsiologiya politiki. Transl. Shmatko, Natalya. Moskva: Socio-Logos, 1993 [Бурдье Пьер, Социология политики. Пер. Шматко, Наталья. Москва: Socio-Logos, 1993].

Cheshko, Valentin, Ivanitskaya, Lyudmila, Glazko Valeriy. "Postindustrial'naya nauka XXI veka - ratsionalizm versus irratsionalizm: evolyutsionno-filosofskiy aspekt." Vestnik rossiyskoy akademii yestestvennykh nauk, 2011, no. 3 [Чешко, Валентин, Иваницкая, Людмила. Глазко, Валерий. “Постиндустриальная наука XXI века - рационализм versus иррационализм: эволюционно-философский аспект.” Вестник российской академии естественных наук, 2011, №3].

Gritsanov, Aleksandr, Abushenko, Vladimir, Yevel'kin, Georgiy et. all. (Ed.). Sotsiologiya: Entsiklopediya. Minsk: Knizhnyy dom, 2003 [Грицанов, Александр, Абушенко, Владимир, Евелькин, Георгий и др. (Ред.). Социология: Энциклопедия. Минск: Книжный дом, 2003].

Gurevich, Pavel. Kul'turologiya. Moskva: Gardariki, 2003 [Гуревич, Павел. Культурология. Москва: Гардарики, 2003]. 
Huizinga, Johan. Osen' Srednevekov'ya. Transl. Silvestrov, Dmitrii. Moskva: Nauka, 1988 [Хейзинга, Йохан. Осень Средневековья. Перев. Сильвестров, Дмитрий. Москва: Наука, 1988].

Il'chenko, Sergey. "Tsennosti 'massovoy kul'tury': perspektivy nauchnogo osmysleniya." Vestnik Sankt-Peterburgskogo universiteta, Zhurnalistika. Ser. 9. 2008, nо. 1 [Ильченко, Сергей. "Ценности «массовой культуры»: перспективы научного осмысления”. Вестник Санкт-Петербургского университета. Журналистика, сер. 9 2008, №1].

Il'ichev, Leonid, Fedoseyev, Petr, Kovalev Sergey, Panov, Viktor (Eds.). Filosofskiy entsiklopedicheskiy slovar'. Moskva: Respublika, 2010 [Ильичев, Леонид, Федосеев, Петр, Ковалев Сергей, Панов, Виктор (Ред.). Философский энциклопедический словарь, Москва: Республика, 2010].

Kapra, Frit'of. Pautina zhizni. Novoye nauchnoye ponimaniye zhivykh sistem, Moskva: ID «Sofiya», 2003 [Капра, Фритьоф. Паутина жизни. Новое научное понимание живых систем, Москва: ИД «София», 2003].

Karpova, Ol'ga. "Astrologicheskiy prognoz kak zhanr massovoy literatury. Obraz chitatelya-potrebitelya." Filologiya $v$ sisteme sovremennogo universitet.skogo obrazovaniya. 2004, no. 7 [Карпова, Ольга. Астрологический прогноз как жанр массовой литературы. Образ читателя-потребителя, «Филология в системе современного университетского образования» 2004, №7].

Khrul', Viktor. "Mediatizatsiya religioznykh tsennostey kak faktor formirovaniya kul'tury dialoga v rossiyskoy zhurnalistike." Vestnik Moskovskogo Universiteta. Ser. 10: Zhurnalistika, 2012, np. 1 [Хруль, Виктор. "Медиатизация религиозных ценностей как фактор формирования культуры диалога в российской журналистике.” Вестніk Москоvskogo Унiversiteta, cep. 10, Журналистика, 2012, №1.]

Kuz'minskaya, Svetlana. "Nekotoryye kharakteristiki ezotericheskogo diskursa." Universum: Filologiya $i$ iskusstvovedeniye: elektron. nauchn. zhurn, 2014, no. 7, 2014.12.22 [Кузьминская, Светлана. "Некоторые характеристики эзотерического дискурса.” Universum: Филология и искусствоведение: электрон. научн. Журн, 2014, №7, 2014.12.22 < http://7universum.com/ru/ philology/archive/item/1455>].

Kuz'minskaya, Svetlana. "Osobennosti funktsionirovaniya metafory v sovremennom ezotericheskom tekste.” Doklad na mezhdunarodnoy nauchnoy konferentsii „Zhivaya Etika i Kul'tura”. Idei naslediya sem’i Rerikhov v nashey zhizni”. Sankt-Peterburgskiy Gosudarstvennyy Universitet kul'tury i iskusstv, 10-11 fevralya 2012, 10.07.2019 [Кузьминская, Светлана. «Особенности функционирования метафоры в современном эзотерическом тексте». Доклад на международной научной конференции ““Жиивая этика и культура.' Идеи наследия семьи Рерихов в нашей жизни.” Санкт-Петербургский Государственный Университет культуры и искусств, 10-11 февраля 2012, 10.07.2019 <http://www.facets.ru/articles12/5028.htm>].

Nazarov, Vladimir, Vvedeniye v ezoteriku, Moskva: Gardariki, 2008 [Назаров, Владимир, Введение в эзотерику, Москва: Гардарики, 2008].

Novozhenova, Zoya. "Kommunikativno-funktsional'nyye svoystva novykh russkikh ezotericheskikh tekstov.” Lyubokha-Kruglik, Yolanta, Malysa, Oksana, Vil'k, Gabriyela, Zykh, Anna (Eds.). Rusistika i sovremennost'. Staryye voprosy, novyye otvety. Katowice: Śląsk-Stowarzyszenie Inicjatyw Wydawniczych, 2017 [Новоженова, Зоя. “Коммуникативно-функциональные свойства новых 
русских эзотерических текстов.” Русистика и современность. Старые вопросы, новые ответы. Любоха-Круглик Йоланта, Малыса Оксана, Вильк Габриела, Зых Анна (Ред.). Katowice: Śląsk-Stowarzyszenie Inicjatyw Wydawniczych, 2017].

Novozhenova, Zoya. “Modal'nost' i tonal'nost' v ezotericheskom tekste.” Kuksa, Irina (Ed.). Kategoriya modal'nosti $v$ rechevoy kommunikatsii: sb. nauch. tr., Kaliningrad: Izd. BFU im. I. Kanta, 2016 [Новоженова, Зоя. "Модальность и тональность в эзотерическом тексте.” Кукса, Ирина (Ред.). Категория модальности в речевой коммуникации: сб. науч.тр., Калининград: Изд. БФУ им. И. Канта, 2016].

Novozhenova, Zoya. "Novaya russkaya frazeologiya: ezotericheskiy vektor.” Avramova, Valentina, Pencheva, Antoniya, Gocho, Gochev i dr. (Eds.). Rusistika: vchera, segodnya, zavtra. Sofiya: Obshchestvo rusistov Bolgarii, 2018 [Новоженова, Зоя. “Новая русская фразеология: эзотерический вектор." Аврамова, Валентина, Пенчева, Антония, Гочо, Гочев и др. (Ред.). Русистика: вчера, сегодня, завтра, София: Общество русистов Болгарии, 2018].

Novozhenova, Zoya. "Russkiy yazyk v novykh diskursivnykh prostranstvakh: reklama... bozhestvennogo." Mir russkogo slova i russkoye slovo $v$ mire. T. 3. Sofia: Heron Press, 2007 [Новоженова, Зоя. "Русский язык в новых дискурсивных пространствах: реклама... божественного.” Мир русского слова и русское слово в мире. Т. 3. Sofia: Heron Press, 2007].

Novozhenova, Zoya. "Ushel v astral i ne vernulsya." Ezotericheskiye frazeologizmy. Zamechaniya k nablyudeniyam." Pstyga, Alicja (Ed.). Stowo z perspektywy językoznawcy i tłumacza, Gdańsk: Wydawnictwo Uniwersytetu Gdańskiego, 2018. [Новоженова, Зоя. “Ушел в астрал и не вернулся...” Эзотерические фразеологизмы. Замечания к наблюдениям.” Pstyga, Alicja (Ред.). Stowo z perspektywy językoznawcy i thumacza, Gdańsk: Wydawnictwo Uniwersytetu Gdańskiego, 2018].

Ogonek 2012, no. 7 (ot 20 fevralya) [Огонек 2012, № 7 (от 20 февраля)].

Pakhomov, Sergey. "Spetsifika ezotericheskogo znaniya v teorii i praktike. Mistiko-ezotericheskiye dvizheniya v teorii i praktike." Pakhomov Sergey (Ed.). Problemy interpretatsii ezoterizma i mistitsizma: cb. materialov Tret'yey mezhdunarodnoy nauchnoy konferentsii. Sankt-Peterburg: RHGA, 2010 [Пахомов, Сергей. “Специфика эзотерического знания в теории и практике. Мистикоэзотерические движения в теории и практике.” Пахомов, Сергей (Ред.). Проблемы интерпретации эзотеризма и мистицизма: сб. материалов Третьей международной научной конференции, Санкт-Петербург: РХГА, 2010].

Pakhomov, Sergey. "Kontury ezoteriologii: eskiz nauchnoŭ distsipliny ob ezoterizme.” Pakhomov Sergey (Ред.). Mistiko-ezotericheskiye dvizheniya v teorii i praktike. "Taynoye i yavnoye": mnogoobraziye reprezentatsiy ezoterizma i mistitsizma. Sb. materialov Chetvertoy mezhdunarodnoy nauchnoy konferentsii, СанктПетербург: РХГА, 2011 [Пахомов, Сергей. "Контуры эзотериологии: эскиз научной дисциплины об эзотеризме”. Пахомов Сергей (Ред.). Мистико-эзотерическиедвижениявтеорииипрактике. Тайноеиявное»:многообразие репрезентаций эзотеризма и мистицизма. Сб. материалов Четвертой международной научной конференции, Санкт-Петербург: РХГА, 2011].

Panychik, Aleksandr. Sotsial'no-filosofskiy analiz ezoterizma. Avtoref. dis. na soisk. uchen. step. k. filos. n. Rostov-na-Donu, 2002 [Панычик, Александр. 
Социально-философский анализ эзотеризма. Автореф. дис. на соиск. учен. степ. к. филос. н. Ростов-на-Дону, 2002].

Parshin, Pavel. Priroda rechevogovozdeystviya, 10.07.2019<http://files.school-collection.edu.ru/dlrstore/4be4c29o-3db5-c4ef-05a5-6aac5078c5b3/1009689A. htm> [Паршин, Павел. Природа речевого воздействия, 10.07.2019 <http://files.school-collection.edu.ru/dlrstore/4be4c29o-3db5-c4ef-05a56aac5078c5b3/1009689A.htm>].

Pelipenko, Andrey, Khachaturyan, Valeriya. "Kognitivnyye istoki 'magicheskogo Renessansa'." Chelovek, 2009, no. 3 [Пелипенко, Андрей, Хачатурян, Валерия. "Когнитивные истоки «магического Ренессанса»." Человек, 2009, №3].

Petrunina, Nadezhda. "Ezotericheskiy element kak yazykovoy znak. (Na materiale liriki U.B. Yyeytsa)." Vestnik Tomskogo gosudarstvennogo universiteta 2011, no. 8 [Петрунина, Надежда. “Эзотерический элемент как языковой знак. (На материале лирики У.Б. Йейтса).” Вестник Томского государственного университета 2011, №8].

Rozin Vadim, Ezotericheskiy mir. Semantika sakral'nogo teksta. Moskva: Editorial, 2002 [Розин Вадим, Эзотерический мир. Семантика сакрального текста, Москва: Едиториал, 2002].

Rzeczycka, Monika. Wtajemniczenie. Ezoteryczna proza rosyjska końca XIX-początku XX wieku, Uniwersytet Gdański, Gdańsk 2010.

Shcheglova, Lyudmila, Borisova, Yuliya. "Rol' ezoteriki v sovremennom nauchnom poznanii." Vestnik Volgogradskogo gosudarstvennogo universiteta. Seriya 7. Filosofiya. Sotsiologiya i sotsial'nyye tekhnologii, 2015, no. 1 [Щеглова, Людмила, Борисова, Юлия. "Роль эзотерики в современном научном познании.” Вестник Волгоградского государственного университета. Серия 7. Философия. Социология и социальные технологии, 2015, №1].

Vorozhbitova, Aleksandra, Romanenko, Lyudmila, "Ezotericheskiǐ diskurs-ansambl' v sisteme diskursivnykh protsessov gnoseologicheski oriyentirovannol kommunikatsii rossiǔskogo sotsiokul'turno-obrazovatel'nogo prostranstva. Lingvoritoricheskiǔ aspekt." Izvestiya Sochinskogo gosudarstvennogo universiteta, 2013, №3 [Ворожбитова, Александра, Романенко, Людмила, “Эзотерический дискурс-ансамбль в системе дискурсивных процессов гносеологически ориентированной коммуникации российского социокультурно-образовательного пространства. Лингвориторический аспект." Известия Сочинского государственного университета, 2013, № 3].

Vovchenko, Vitaliy, "Mistitsizm, ezoterizm i okkul'tizm v dukhovnoy evolyutsii chelovechestva". Pakhomov, Sergey (Ed.). Mistiko-ezotericheskiye dvizheniya v teorii i praktike. Problemy interpretatsii ezoterizma i mistitsizma, Sankt-Peterburg: RHGA, 2010 [Вовченко, Виталий, «Мистицизм, эзотеризм и оккультизм в духовной эволюции человечества». Пахомов, Сергей (Ред.). Мистикоэзотерические движения в теории и практике. Проблемы интерпретации эзотеризма и мистицизма. Санкт-Петербург: РХГА, 2010].

Yulina, Nina. Dzhordzh Santayana. Voobrazheniye, zhivaya vera $i$ "tsarstva bytiya”. Filosofskaya mysl'v SSHA XX v., Moskva: «Kanon+» ROOI «Reabilitatsiуа», 2010 [Юлина, Нина. Джордж Сантаяна. Воображение, живая вера u «царства бытия», Философская мысль в США ХХ в., Москва: «Канон+» РООИ «Реабилитация», 2010].

Zinov'yev, Aleksandr. Na puti $k$ sverkhobshchestvu, Moskva: ZAO Izd-vo Tsentrpoligraf, 2000 [Зиновьев, Александр. На пути к сверхобществу, Москва: ЗАО Изд-во Центрполиграф, 200о]. 
МИСТИКО-ЭЗОТЕРИЧЕСКИЕ ЦЕННОСТИ...

Zorina, Yelena. Russkaya metafizika i ezotericheskaya traditsiya. XX vek, Yoshkar-Ola: Mariyskiy gosudarstvennyy universitet, 2000 [Зорина, Елена. Русская метафизика и эзотерическая традиция. ХХ век, Йошкар-Ола: Марийский государственный университет, 2000].

Zoja Nowożenowa

MISTYCZNO-EZOTERYCZNE WARTOŚCI VS WARTOŚCI KULTURY MASOWEJ W KOMUNIKACYJNYCH PRAKTYKACH ROSJAN: KONFLIKT INTERESÓW

Streszczenie

W artykule analizie został poddany proces kształtowania się w komunikacyjnej przestrzeni Rosji dyskursu ezoterycznego, przejawiającego i propagującego wartości ezoteryczne. Na peryferiach tego dyskursu, przede wszystkim w przestrzeni medialnej, zaobserwowane zostało zjawisko „wtargnięcia” do obszaru ezoterycznego wartości kultury masowej. Na poziomie praktyk dyskursywnych objawia się to w deformowaniu kanonów gatunków dyskursu ezoterycznego - horoskopu i gatunku kultury masowej - reklamy. Proces ów daje się zaobserwować w celowym doborze środków językowych w celach stworzenia porządku dyskursu.

Zoya Novozhenova

MYSTIC AND ESOTERIC VALUES VS VALUES OF THE MASS CULTURE IN COMMUNICATIVE PRACTICES OF RUSSIANS: THE CONFLICT OF OBJECTIVES

Summary

In the article the author analyzes the process of creation in the communicative space of Russia of the esoteric discourse presenting and spreading esoteric values. On the periphery of this discourse, in the media space, we can observe the "invasion" of the mass culture into the field of esoteric values. On the level of discursive practices it occurs in deformation of the canon of esoteric genres - horoscope and mass culture genre - advertising. The process manifests in purposeful choice of language means helping to create the order of the discourse. 